\title{
Domino Effect of Coronavirus in Nigeria. An Overview of the Socioeconomic, Religious and Educational Perspectives
}

\author{
Abinotami Williams Ebuete ${ }^{1,2^{*}}\left(\mathbb{D}\right.$, Okpoebi Kenneth Berezi $^{3}$, Lucky E. Ndiwari' ${ }^{1}$, Standfast Isiya ${ }^{4}$ \\ ${ }^{1}$ Department of Geography and Environmental Management, Niger Delta University, Amassama, Niger \\ ${ }^{2}$ Environmental Health and Sanitation Department, Bayelsa State Ministry of Environment, Yenagoa, Niger \\ ${ }^{3}$ Department of Marine Environment and Pollution Control, Nigeria Maritime University, Okerenkoko, Niger \\ ${ }^{4}$ Environmental Health and Sanitation Department, Federal Medical Centre, Yenagoa, Niger \\ Email: *ebuetewilliams@gmail.com
}

How to cite this paper: Ebuete, A.W., Berezi, O.K., Ndiwari, L.E. and Isiya, S. (2021) Domino Effect of Coronavirus in Nigeria. An Overview of the Socioeconomic, Religious and Educational Perspectives. Open Access Library Journal, 8: e6967 https://doi.org/10.4236/oalib.1106967

Received: November 8, 2020

Accepted: May 24, 2021

Published: May 27, 2021

Copyright $\odot 2021$ by author(s) and Open Access Library Inc.

This work is licensed under the Creative Commons Attribution International License (CC BY 4.0).

http://creativecommons.org/licenses/by/4.0/

\begin{abstract}
The human history has recorded that in every 100 years a new pandemic will erupt to rocked control the human race from over population, changing the courses of history and signaling the end of entire civilization. Today the world is at halt and its economic, socio-cultural, religious, political, scientific and technological myth is degenerating amidst the advent of a novel pandemic (COVID-19). This study therefore, investigated the effect of COVID-19 in terms of economic, socio-cultural, educational and religious factors which are best described using students, private sectors, public servants, religious bodies and farmers as sectoral factors. The paper also addressed geopolitical regional zones differences in the effect of COVID-19 in Nigeria using schedules as a model for data collections. Generated data were analyzed using percentages, Two-way ANOVA and Co-Variance (ANOCOVA) to test for significant differences amidst the effects of COVID-19 among domain, sectors and geopolitical regions. Findings from the study show that $96 \%$ student's educational process was negatively affected and about $94 \%$ economic values of privately owned business were grossly affected; $53 \%$ socio-cultural activities brought down because of the stay-at-home order; $58 \%$ religious activities (worship centre) were affected on the approval of only 20 members per 2 meters distancing in a service. More so, farmers experiences $58 \%$ economic loss underscored with an endemic increase in the price of major food items. The interactions term between COVID-19, domain and sector is not significant as it was felt equally on Domain and on sectoral factors. On the other hand, the effect of COVID-19 is felt differently among geopolitical regions in Nigeria owing to socio-cultural, economic, political and population
\end{abstract}


difference. The paper therefore, recommended for the formulations and implementations of workable health care, social and educational welfare policies that respond and recover quickly to related disease; while relying more on domesticated products and byproducts.

\section{Subject Areas}

Anthropology, Economics, Education

\section{Keywords}

COVID-19, Nigeria, Economic, Socio-Cultural, Educational,

Religious and Geopolitical

\section{Background to the Study}

Corona virus is a novel pandemic rocking the human planets mostly coined from the phrase COVID-19 (CO means Corona; VI meaning virus, D stands for diseases and 19-year 2019 of its identification). Coronavirus belongs to the $\mathrm{Co}$ ronaviridae family in the Nidovirales order and it represents crown-like spikes on the outer surface of the virus; thus, it was named as a Coronavirus (Muhammad, Suliman, Abeer, Nadia\&Rabeea, 2020) [1]. It came with mild symptoms ranging from fever (85\% - 99\%), Cough (59\% - 82\%), Headache (34\% - 88\%), fatigue $(44 \%-70 \%)$, lack of appetite $(40 \%-84 \%)$, shortness of breath $(31 \%-$ $40 \%)$, Mucus/phlegm $(28 \%-33 \%)$, sore throat $(36 \%-78 \%)$ and body aches (11\% - 35\%) to sever Acute Respiratory Syndrome (SARS 5\%) and Middle East Respiratory syndrome (MERS 2\% - 7\%), situations that can claim human life. The remote cause of the virus is arguably arousing research interest but Wuhan city in China is the epicenter of the 2019 human Coronavirus epidemic, with recorded figure of about 50,333 cases including death toll of 3869 as of $17^{\text {th }}$ April, 2020 when this work was conceived. However, due to containment failure on the part of China, it has spread to over 210 countries in the seven continents amounting to about 2,331,099 confirmed cases with a death toll of 160,952 globally as of 17/4/2020 (ECDPC, 2020 [2]; Worldometer, 2020 [3]).

It is a mind blowing fact that in every 100 years a new pandemic will erupt to rocked control the human race from over population, changing the courses of history and signaling the end of entire civilization; such of these pandemic includes the Great Plague of Marseille of 1720 with a deaths toll of 100,000; Cholera pandemic of 1820 (3 million deaths); Spanish flu of 1920 (50 million deaths) and Coronavirus of 2020 (154,268 deaths) (Owen, 2020 [4]; Devaux, 2013 [5]). Interestingly, $60 \%-75 \%$ of these infectious diseases are zoonotic (comes via animal to human). However, lessons from previous and current pandemics about early containment, social distancing, self-isolation and total lockdown as mainstream practices in the affected countries, the death toll is likely to be much lesser than the three greats pandemics of the $20^{\text {th }}$ century viz: Spanish Flu 1920 
(50 million deaths); Asian Flu 1958 and Hong Kong Flu in 1968 (4 million deaths each). Arresting from these containment practices in the absent of vaccine, mother earth is gradually restoring (rehabilitated) from the ill cause of civilization, industrialization and overpopulation. From cleaner air to liberated wildlife and from industrial to socio-economic perspective, coronavirus lockdown across the world appear to have had a number of paradoxical effects on the environment and the world economy respectively. Iteming is cleaner air due to plummet of pollutions which has enable citizens in Northern India viewing the Himalayan mountain range for the first time in 30 years, while those living in Jalandhar in northern Punjab have shared pictures of the mountains from rooftops and empty streets, amazed by the view which has been hidden by pollution for 30 years. On the contrary, Tom, Jamie, Maeva and Jinshan (2020) [6] reported that the coronavirus lockdown has caused the global economy $\$ 2.7$ trillion as stock markets worldwide which is the largest single decline since the 2008 financial crisis and it will eventually lead to the deepest depression since 1929 (Jones, Brown \& Palumbo, 2020) [7]; Nigerians receiving the hardest hit on the economy, since almost $80 \%$ of Nigerian revenue is derived from crude oil but the current pandemicsituations relegated the price of crude oil to as low as $\$ 20$ per barrel from above $\$ 60$ which is far less than the budget's benchmark of $\$ 57$ per barrel, signifying tough times ahead (Ogunde, 2020) [8]. In the light of the double whammy of the declining oil demand and oil prices as a result of the COVID-19 pandemic, government revenue would continue to fall in subsequent months beginning from the month of March, 2020 (NEITI, 2020) [9] and inflation rate expected to grow from $0.26 \%$ to $1.21 \%$ according to the Consumer Price Index (CPI), 2020. This study therefore, envisaged an account effect of coronavirus on the Economic, Socio-cultural, educational and religious life of $\mathrm{Ni}$ gerians by outlining the negative effect of coronavirus and identify the failure of government political will in addressing the challenging effect of coronavirus on both independence and dependent populace.

\section{Material and Methods}

\subsection{Study Design and Method of Data Collection}

The study adopted the descriptive designed; purposively and randomly involving 180 piece of structured schedules with a sample size of 124 schedules administered to 31 persons as determined by the Taro Yamane and Bowler's proportional formulae respectively (Rafael, 2014) [10] to the respective targeted sectors (domain) in Nigeria; covering the Economic, Socio-cultural, Educational and Religious aspects of the society. According to Kothari and Garg (2016) [11], Schedules are Performa containing a set of questions that are generally filled by the researcher or enumerator, who interpret questions when necessary to the targeted population. This therefore, save time, resources and exposed the researcher to real life experience while reducing non-response. So much more, much of the information captured in this study is sourced from the Nigerian 
Table 1. Calculated sample size of each study group.

\begin{tabular}{ccc}
\hline STUDY GROUP & $\begin{array}{c}\text { ASSIGNED SAMPLE } \\
\text { SCHEDULES }\end{array}$ & $\begin{array}{c}\text { SAMPLE SIZE OF EACH GROUP } \\
\mathbf{n}\left(\mathbf{n}_{1}\right) / \mathbf{N}\end{array}$ \\
\hline Economical $\left(\mathrm{n}_{1}\right)$ & 45 & $124 \times 25 / 100=31$ \\
Socio-cultural $\left(\mathrm{n}_{1}\right)$ & 45 & $124 \times 25 / 100=31$ \\
Educational $\left(\mathrm{n}_{1}\right)$ & 45 & $124 \times 25 / 100=31$ \\
Religious $\left(\mathrm{n}_{1}\right)$ & 45 & $124 \times 25 / 100=31$ \\
\hline
\end{tabular}

Center for Disease Control (NCDC) and other secondary data released (published) with regards to the pandemic while the study was conducted. To elucidate the aim and objectives of the study, the study area is grouped into four (4) targeted sectors (domain) viz: The Economic; Socio-cultural; Educational and Religious group (Table 1). Other public opinion and focused group discussion was also engaged while observing all COVID-19 protocols such as the social distancing to dilate the subject of interest.

The sample size is determined following Taro Yamane sample size determination formula of

$$
n=N / 1+N(e) \quad(\text { Rafael, 2014) [10] }
$$

where: $N$ is the population size (180) and (e) is the significant level $(0.05 \%)$, resulted to 124 sample size.

Furthermore, the number of schedules administered to each group was computed using Bowler's proportional allocation formulae as

$$
n_{1}=n\left(n_{1}\right) / N \quad(\text { ibid, 2014) [10] }
$$

where: $N$ is the population size (180); $\mathrm{n}$ is the sample size (124), resulted to 31 numbers of schedules administered among groups respectively.

\subsection{Sample and Analysis Techniques}

\subsubsection{Samples}

Samples from this study extracted from the schedules were computed to determine the influence of COVID-19 19 on domain factors such as the economic, social-cultural, educational and religious life were explained/determined on sectoral basis in terms of students, private sectors (business), public servants and farmers (Table 2). Furthermore, the domain effects were also view based on geopolitical regions. The Nigerian political system of government (Federalism) regrouped the country into six (6) major geopolitical regions; each region is constituted with five-to-seven states that make up the thirty-six states and additional Federal Capital Territory (FCT) in the North-Central region. The Geopolitical Regions are the South-South (6 states), South-East (5 states), South-West (6 states), North-Central (7 states), North-East (6 states) and North-West (7 states), reason been for economic and governance differences.

\subsubsection{Analysis Techniques}

Field data were presented in percentages were necessary. Further analysis of 
Table 2. Results presentations in percentages.

\begin{tabular}{|c|c|}
\hline $\operatorname{AGE}(n=124)$ & Percentage Frequency \\
\hline $15-25$ years & $38(31 \%)$ \\
\hline $26-36$ years & $32(26 \%)$ \\
\hline $37-47$ years & $29(23 \%)$ \\
\hline 48 - 58 years & $25(20 \%)$ \\
\hline TOTAL & $124(100 \%)$ \\
\hline \multicolumn{2}{|l|}{$\operatorname{SEX}(n=124)$} \\
\hline Female & $68(55 \%)$ \\
\hline Male & $56(45 \%)$ \\
\hline TOTAL & $124(100 \%)$ \\
\hline \multicolumn{2}{|c|}{ SECTORS $(\mathrm{n}=124)$} \\
\hline Students & $25(20 \%)$ \\
\hline Private Sector & $36(29 \%)$ \\
\hline Public servants & $30(24 \%)$ \\
\hline Farmers & $33(27 \%)$ \\
\hline TOTAL & $124(100 \%)$ \\
\hline \multicolumn{2}{|c|}{ GEOPOLITICAL REGIONS ( $\mathrm{n}=124$ ) } \\
\hline South-South & $25(20 \%)$ \\
\hline South-East & $23(19 \%)$ \\
\hline South-West & $20(16 \%)$ \\
\hline North-Central & $19(15 \%)$ \\
\hline North-East & $18(15 \%)$ \\
\hline North- West & $19(15 \%)$ \\
\hline TOTAL & $124(100 \%)$ \\
\hline
\end{tabular}

Source: Researcher 2020.

variance such as the Two-Way ANOVA was used to test for statistical significant difference on the effect of COVID-19 on Domain and Sectoral, while the analysis of Co-Variance (ANOCOVA) was used to test for statistical significant difference in the effect of COVID-19 among Geopolitical regions in Nigeria. The Two-Way ANOVA was adopted because the data were classified on the bases of two factors (Domain and Sectors). Kothari and Garg (2016) [11] open that ANOCOVA techniques removed the influences of uncontrolled variables through simple linear regression method and the residual sums of squares are used to provide variance estimates which in turn were used to make tests of significance.

\section{Results and Discussions}

Table 3 shows that all the three (3) F-ratios are not significant at $0.05 \%$ (F-ratio $>5 \%$ ), which means that the influence of COVID-19 was felt equally on 
Table 3. ANOVA table for adjusted domain and sector.

\begin{tabular}{cccccc}
\hline Source & SS & D.F & MS & $F$-ratio & 5\% limit \\
\hline B/W Columns (Domain) & 7672 & 3 & 2557.3 & 13.03 & $3.16=3.24$ \\
B/W Rows (Sector) & 7804 & 3 & 2601.3 & 13.26 & $3.16=3.24$ \\
Interactions variations & 9031 & 9 & 1003.4 & 5.113 & $9.16=2.54$ \\
Within Samples (Error) & 3140 & 16 & 196.25 & & \\
Total & $\mathbf{2 7 , 6 4 7}$ & $\mathbf{3 1}$ & & & \\
\hline
\end{tabular}

Source: Research, 2020.

Domain factors, so also on the sectoral factors. Hence, the interactions term between COVID-19, domain and sector is not significant.

Students: The life and operations of students were in jeopardy amidst the pandemic globally. According to the report of UNESCO, 2020 (UNESCO a\&b, 2020) [12] [13], about 1.5 billion students worldwide from 192 countries (Nigeria inclusive) were ordered to stay at-home on April $15^{\text {th }}, 2020$ amidst the pandemic. In Nigeria, both private, public schools and universities were closed on March $30^{\text {th }}, 2020$; students were sent back home; following the lockdown executive order, in the absent of digital economy. Unlike in a robust and well-developed economy were e-Education enable educators and student even at quarantined state access and learn digitally through e-Education apps without hampering/ bridging on their educational process. The few online classes operating during the first peak of the pandemic were faced with anxiety that affect negatively on students physiological, emotional and behavioral states; similar scenario in India (Dangi \& George, 2020 [14]; Wang, Zhang, Zhao, Zhang \& Jiang, 2020 [15]). However, on a general note the Nigerian situation was like a shadow of itself as the stay-at-home order interrupted learning, depriving students to opportunities, growth and development; causing poor nutrition since free and discounted meals provided at schools were compromised by the order; gaps in childcare were created leading to peer pressure and substances abuses; rising school dropout rates; social isolation as school stands to be the hubs of social activities and human interactions; exposure to violence and exploitations; recording high cost of economic losses. Similarly, Wang, Zhang, Zhao, Zhang and Jiang (2020) [15] concluded that school closure reduces student eating/sleeping patterns and physical activities but promote longer screen time, increases stress and less social interactions which pose risk to their physical and mental health. School closures impact not only student but teachers as well, hence the indignations was on private teachers/tutors sourcing living through the academic sections.

Table 4 shows that $96 \%$ (24) of student's educational processes were negatively affected by COVID-19. Students socio-cultural life $88 \%$ (22) were also affected, students' economic values stripped down by $72 \%$ because they were at home with parents at lockdown situation, also the religious aspects as religious gathering beyond 20 persons were prohibited by the federal and state order. This led to the cancellation of worship services, pilgrimages surrounding observances 
Table 4. Domain response per sector.

\begin{tabular}{cccccc}
\hline $\begin{array}{c}\text { Sector/Domain } \\
\text { Effects }\end{array}$ & Economic & Socio-cultural & Educational & Religious & Total \\
\hline Student $(\mathrm{n}=25)$ & $18(72 \%)$ & $22(88 \%)$ & $24(96 \%)$ & $10(40 \%)$ & $74: 26(100)$ \\
& $7(28 \%)$ & $3(12 \%)$ & $1(4 \%)$ & $15(60 \%)$ & \\
Private $(\mathrm{n}=36)$ & $34(94 \%)$ & $19(53 \%)$ & $20(56 \%)$ & $21(58 \%)$ & $94: 50(144)$ \\
& $2(6 \%)$ & $17(47 \%)$ & $16(44 \%)$ & $15(42 \%)$ & \\
Public $(\mathrm{n}=30)$ & $25(83 \%)$ & $6(20 \%)$ & $18(60 \%)$ & $10(33 \%)$ & $59: 61(120)$ \\
& $15(17 \%)$ & $24(80 \%)$ & $12(40 \%)$ & $20(67 \%)$ & \\
Farmers $(\mathrm{n}=33)$ & $19(58 \%)$ & $4(12 \%)$ & $19(58 \%)$ & $22(67 \%)$ & $64: 68(132)$ \\
& $14(42 \%)$ & $29(88 \%)$ & $14(42 \%)$ & $11(33 \%)$ & \\
Total $(\mathrm{n}=124)$ & $96: 38(124)$ & $51: 73(124)$ & $81: 43(124)$ & $63: 61(124)$ & $29: 205(496)$ \\
\hline
\end{tabular}

Source: Researcher, 2020.

and festivals while putting an end to in-person worship based on the ecclesiological, liturgies and ways worship centres were managed as it was almost the same in all the countries experiencing the effects of COVID-19 respectively according to Sulkowski and Ignatowski (2020) [16].

Private: One of the worst bashed sectors during the COVID-19 pandemic is the private sector; although there were some levels of uncertainty about the future economic outlook as it may possess significant challenges when making estimates and assessing private business ability to continue became a growing concern. Sectors like companies, banking industries, pharmaceutical, manufacturing/productions, marketing and distributions industries, tourism and recreational centres, private religious centres, Hotels, Restaurants, bars, sports, clubs etc. were partially and permanently closed down to collectively fight the deadly disease (COVID-19), and it is an inkling fact that the above sectors survive/strived with populations influx. However, the simultaneous combat of the virus discourages public gatherings by $90 \%$ and encourages social distancing by $89 \%$ (NBS, 2020) [17] an action that led to economic lost. The shutdown of financial markets, corporate offices, businesses and events prompt supply shocks in the global supply chain as many importers shut down their factories and closed their borders particularly China and United Kingdom who emerged as the Nigerian top source of capital investment with a total of $\$ 5854.38 \mathrm{~m}$ in the first quarter of 2020; this witnessed shortage of crucial supplies like pharmaceutical supplies, spare parts, and finished goods (NBS, 2020 [17]; NBS Q1, 2020 [18]). Furthermore, the private workforces dropped drastically as most companies were on redundancy and could not pay their workers, paving way to finance and liquidity, tax trade and regulatory, strategy and brand; hence driving resources from development efforts to crisis response.

From Table 4, about 94\% economic values of privately owned business was grossly affected; $53 \%$ socio-cultural activities brought down especially in the recreational and tourisms services; private schools (56\%) like mono-techniques, polytechnics, colleges, universities were temporarily shut down to contain the 
disease reflecting the negative effects of the disease on both the academic and non-academic staff. 58\% religious' activities (Worship Centres) were affected on the approval of only 20 members per 2 meters distancing in a service; turning so many private staff workers into beggars has been relieved from their sources of livelihood.

This further triggers major social problems in Nigeria ranging from child abandonment, armed robbery, homelessness, mental health problems, divorce, Suicides, homicides, unplanned pregnancies, arousing anti-social groups to problems of single parenting in the absent of social welfare policy and programme. The situation became more evident as states repatriated Sai Baba Almajiri and prostitutes back to their states of origin as a way of containing the pandemic while managing available resources since majority of Nigerians thought to be living on less than $\$ 1.90$ a day.

Public Sectors: The Nigerian populace like any other countries witnesses the negative effects of the pandemic. It became more glaring as the Federal Account Allocation Committee (FAAC), monthly disbursement for Federal, States, Local governments and Others dwindled from 780.926 billion naira in March, 2020 to 547.309 billion naira only in the month of May, 2020 (NEITI, 2020) [9]; falling below the estimated minimum thresholds for the three tiers of the government and others to meet their current obligations. It became so serious that more resources need to be channeled to the health sector to combat the pandemic, resulting to the movement of funds from other sectors hitherto identified as critical in their budgets coupled with the view to revise the budget to prepare for lower FAAC disbursement.

On a practical note, the public servants are the custodians of public goods and are indispensible conduct for crisis recovery. But on the contrary, the pandemic droved in major changes in the public sector which dramatically affects public finances causing unethical behaviour on government support schemes. The study further shows that the Nigerian populace also witnessed distinct effects of the pandemic among the public urban and the rural dwellers; as most government stringent laws and curfew were implemented more in the urban centers considering population size. This was further captured in the report of National Bureau of Statistics (NBS, 2020); stating that some households struggled to purchase staple foods like yam, rice and beans during the 7 days stay-at-home order and about $35 \%-59 \%$ of households who need to purchase these staple foods reported that they were unable able to buy them due to changes in commodities price while $26 \%$ of households reported not being able to access medical treatment when they needed it in the same period (NBS, 2020) [17]. The period cakes with an endemic increase in the price of major food items consumed (85\% of households) and farming/business inputs (46\%) were most widely experienced.

Farmers: Evidence of the pandemic is impacting on every agricultural sectors and types of agriculture, such that both substantial farmers, commercial, mechanized etc experience limited access to both raw material and agricultural bypro- 
ducts, logistics constraints and labour shortages, prompted serious disruptions of economic activities, particularly nonfarm business closure (36\%) and disruption of farming activities (29\%) according to the National Bureau of Statistics (NBS, 2020 [17]; NBS Q1, 2020 [18]).

Table 4 shows that farmers experiences $58 \%$ economic loss and only $12 \%$ socio-cultural loss which can be attributed to the incessant price increased on farm products over the first quarter of the pandemic. On the other hand, the pandemic further impeded access to food as incomes fall, remittances were lost and in some context, the rising food prices promote hunger and undernourishment thus, changing the purchasing power of Nigerians even in the face of product quality and quantity reductions. The OECD-FAO Agricultural Outlook of 2020-2029 stated that the pandemic knock-on effects aggravated preexisting drivers of hunger which by their forecasting will depress demand and further undermine food security by pushing 40 - 60 million people to extreme poverty. Evidently, the State of Food Security and Nutrition (SOFI, 2020) reported that about 920 million people will be pushed to chronic hunger by the end of 2020 making the zero hunger Sustainable Development goal by 2030 doubtful to achieve.

The effects doubled on the non-farming families. To a large extent, non-farming family had no option but to soar in with the dynamic changes of staple food price in the market due to interstate banned (rural-urban) on traveling causing shortage of available food items. On the other hand, the farmers we're deprived access to farming inputs to boost productions yet there was a shortage of storing space as product mark for sale hardly find its way to the market causing economic loss. Further studies by NBS (2020) [17] revealed that the high rate of household income loss was highest for non-farm family business (85\%) compared to household farming, livestock or fishing (73\%) and wage employment (58\%). Complementing the above, Ozili (2020) [19] captured that in the year 2019, consumption expenditure in the rural areas surpassed that in the urban centers (rural spending stood at $\$ 21.1$ trillion, $10.4 \%$ higher than $\$ 19.1$ trillion spent in the urban centres). Food and non-food expenditure in the urban centres stood at $51.5 \%$ percent and 48.5 percent respectively as against 61.3 percent and 38.7 percent of rural consumption expenditures. The gap was further widened during the pandemic period since most primary economic activity is taken place in the rural area. The economic shocks was worst following the geometrical increases in the price of major food items consumed (85\% of households) and farming/business inputs (46\%) widely experienced as stirred by the panic buying (NBS, 2020) [17].

From Table 5, the F-ratio is not significant (F-ratio $<0.05 \%$ limit), which mean that the effect of COVID-19 is felt differently among geopolitical regions in $\mathrm{Ni}$ geria and as at the time of this writing (26/3/2020), Nigeria has recorded 8344 confirmed cases, 2385 recovered and 249 deaths (NCDC.gov.ng, 2020). Figure 1 shows that the South-West geopolitical region alone recorded 4265 (53\%) cases; 
North-West 1713 (21\%); North-Central 777 (10\%); North-East 720 (9\%); South-South $511(6 \%)$ and South-East 109 (1\%); representing the weak capacity of the health care systems in the country; couple with the poor hygiene conditions of larger populations and doubled by the structural inequalities and discriminatory policies which is likely to exacerbate the pandemic and its impact on the domain and in various sectors (Table 6). The numbers of death casualties according to geopolitical zones were SW (132), NW (52), NC (25), NE (22), SS (15) and SE (3) respectively as of 26/3/2020.

The first cessation of all movement as directed by President Muhammadu Buhari on Monday, $30^{\text {th }}$ March, 2020 affects only Lagos and Ogun state in the South-West region and Abuja in the North-Central region. Anecdotally, the southwest region followed by North Central region received the hardest hit as the first recorded index case was noted in Lagos with a travel historical destination at Ogun and Abuja respectively; this brought about the shutdown of these major states (business hub, centre of tourism and destination to migrants) with an untold economic shock, consequent upon COVID-19. The lock down (stay-at-home-order) in the absent of palliatives and people friendly policies further promotes human right abuses and violence against vulnerable and poor groups which in turn marred the containment measures as social distancing

Table 5. ANOVA Table for Adjusted Y (Yes).

\begin{tabular}{cccccc}
\hline Source & d.f. & SS & MS & F-ratio & 5\% Limits \\
\hline B/W Groups & 3 & $6,971,929,346.97$ & $2,323,976,448.990$ & 0.348 & $3.19=31.3$ \\
Within Groups & 19 & $127,051,999,787.95$ & $6,686,947,367.94$ & & \\
Total & 22 & $134,023,929,134.9$ & $9,010,923,816.93$ & & \\
\hline
\end{tabular}

Source: Researcher, 2020.

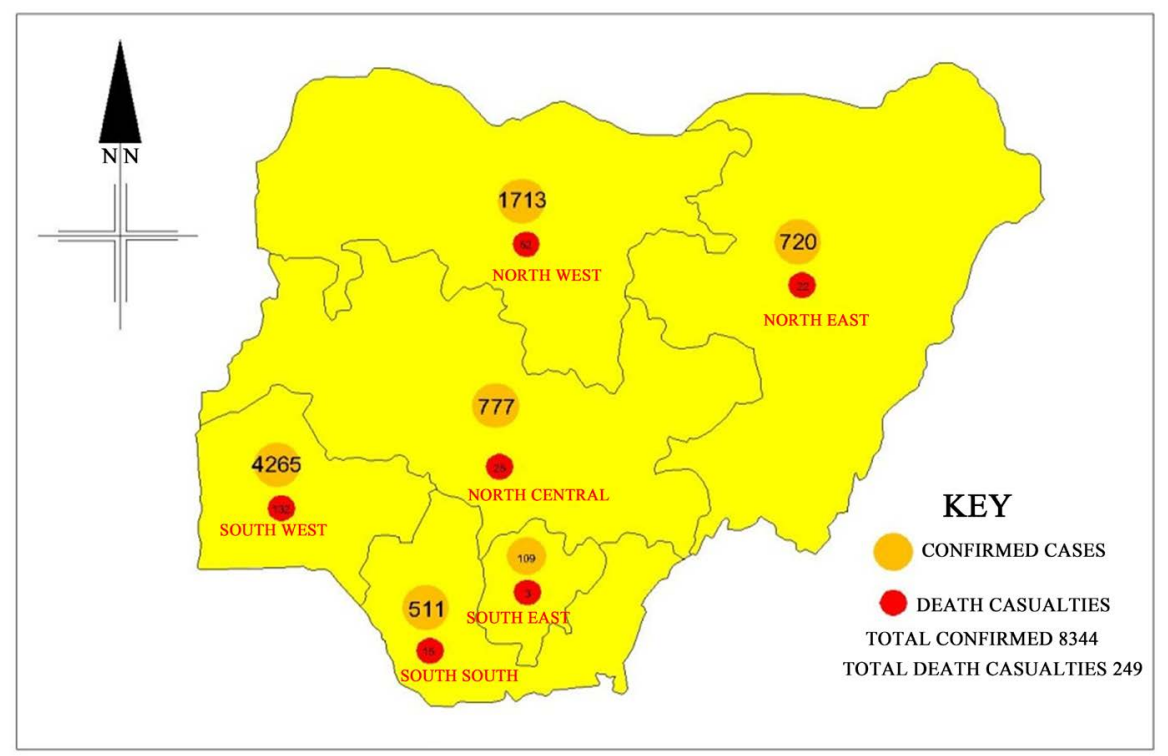

Source: Researchers, 2020. Edited/crafted from COVID-19.ncdc.gov.ng, 26/05/2020.

Figure 1. COVID-19 index cases per geopolitical regions in Nigeria. 
Table 6. COVID-19 effects on domain per geopolitical regions in Nigeria.

\begin{tabular}{cccccccccc}
\hline \multirow{2}{*}{$\begin{array}{c}\text { Geopolitical/ } \\
\text { Domain }\end{array}$} & \multicolumn{2}{c}{ Economic } & \multicolumn{2}{c}{ Socio-cultural } & \multicolumn{2}{c}{ Educational } & \multicolumn{2}{c}{ Religious } & \multirow{2}{*}{ Total } \\
\cline { 2 - 8 } & Yes & No & Yes & No & Yes & No & Yes & No & \\
\hline SS & 12 & 13 & 21 & 4 & 24 & 1 & 23 & 2 & 100 \\
$\mathrm{n}=25$ & $(48 \%)$ & $(52 \%)$ & $(84 \%)$ & $(16 \%)$ & $(96 \%)$ & $(4 \%)$ & $(92 \%)$ & $(8 \%)$ & \\
SE & 17 & 6 & 19 & 4 & 22 & 1 & 21 & 2 & 92 \\
$\mathrm{n}=23$ & $(74 \%)$ & $(26 \%)$ & $(83 \%)$ & $(17 \%)$ & $(96 \%)$ & $(4 \%)$ & $(91 \%)$ & $(9 \%)$ & \\
SW & 14 & 5 & 16 & 3 & 18 & 1 & 18 & 1 & 76 \\
$\mathrm{n}=19$ & $(74 \%)$ & $(26 \%)$ & $(84 \%)$ & $(16 \%)$ & $(95 \%)$ & $(5 \%)$ & $(95 \%)$ & $(5 \%)$ & \\
NC & 13 & 6 & 13 & 6 & 18 & 1 & 17 & 2 & 76 \\
$\mathrm{n}=19$ & $(68 \%)$ & $(32 \%)$ & $(68 \%)$ & $(32 \%)$ & $(95 \%)$ & $(5 \%)$ & $(89 \%)$ & $(11 \%)$ & \\
NE & 10 & 8 & 11 & 7 & 16 & 2 & 16 & 2 & 72 \\
$\mathrm{n}-18$ & $(56 \%)$ & $(44 \%)$ & $(61 \%)$ & $(39 \%)$ & $(89 \%)$ & $(11 \%)$ & $(89 \%)$ & $(11 \%)$ & \\
NW & 10 & 9 & 12 & 7 & 17 & 2 & 17 & 2 & 76 \\
$\mathrm{n}=19$ & $(53 \%)$ & $(47 \%)$ & $(63 \%)$ & $(37 \%)$ & $(89 \%)$ & $(11 \%)$ & $(89 \%)$ & $(11 \%)$ & \\
TOTAL & 76 & 47 & 92 & 31 & 115 & $\mathbf{8}$ & 112 & 11 & 492 \\
\hline
\end{tabular}

Source: Researcher, 2020. Note: Data are presented as $\mathrm{Y}=\mathrm{Yes}$ or $\mathrm{N}=\mathrm{No}$ in percentages.

almost became impossible due to overcrowding of displaced persons in these regions. On a global scale, Nigeria takes the 8th position with the highest recorded internally displaced persons (UNHCR, 2014) [20] and according to the Internal Displacement Monitoring Centre, an average expected number of displacement per year for sudden onset hazards in Nigeria stood at 214,426 fueled by armed violence, suicide attacks, Abductions, sexual violence, inter-communal crisis, religious violence and pastoralist against farmers clashes etc. (Okon, 2018 [21]; Olanrewaju et. al, 2019 [22]; Etikan \& Babatope, 2019 [23]), with a reflecting image of malnutrition, unemployment, death, overcrowding etc.withinthe Internally Displaced Persons (IDPs) camps and informal settlements making the North Central and North West regions more vulnerable to COVID-19 pandemic). On the other hand, the southwest region ranks highest in COVID-19 index cases due to overpopulation. Research by Roberts and Okanya (2020) [24] revealed that Lagos state (most populated state in the southwest region and Africa) is receiving some 123,000 migrants daily including many IDPs putting the available limited resources under stress, an act that make social distancing almost impossible, report toeing the same path with the report of Giannik and Bruggema (2019) [25]. This was recalled and emphasized by WHO (2020) [26] and Ebuete et al. (2020) [27] that the provision of safe water, sanitation and hygienic conditions is essential for the protection of human health during all infectious diseases outbreak while the consistent application of WASH and waste management practices in all homes, business centres and health care services will help prevent disease transmission.

\section{Summary and Conclusion}

In Nigeria, the reason why the outbreak became uncontrollable and caused suf- 
fering to poor citizens was because of weak and ineffective institutions in responding to the pandemic; absence or lack of social welfare programs that will cater for poor citizens and vulnerable citizens. Upon these, the industries that could have aid quick recovery of the economy is facing problems such as poor infrastructural and unreliable utilities, scarcity of skilled workers, poor access to finance, lack of appropriate government incentives, policy incoherence by the government, poor demand due to robust competition from Asian companies particularly China, high cost of doing business as a result of imported and expensive production inputs, regulatory problems, among others. The study argued that the level of development in a country plays an important role in prolonging economic crises and also in facilitating economic recovery. The developing Nigerian economy settled fear of financial and economic collapse that led to panic buying, hoarding of foreign currency by individuals and businesses for speculative reasons, flight to safety in consumption, household stocking upon essential food and commodity items, staffs working from home to reduce operating costs, as income sources were affected by the pandemic. The pandemic further impeded access to food as income fall, remittances were lost and in some context's obnoxious rise in food prices, promoting hunger and undernourishment thus, changing the purchasing power of Nigerians even in the face of product quality and quantity reductions. The effect was so glaring as $96 \%$ student's educational process was negatively affected and about $94 \%$ economic values of privately owned business were grossly affected; 53\% Socio-cultural activities brought down because of the stay-at-home order; $58 \%$ religious activities (worship centres) were affected on the approval of only 20 members per 2meters distancing in a service. More so, farmers experience $58 \%$ economic loss underscored with an endemic increase in the price of major food items. The interaction term between COVID-19, domain and sector is not significant as it was felt equally on Domain and on sectoral factors. On the other hand, the effect of COVID-19 is felt differently among geopolitical regions in Nigeria owing to socio-cultural, economic, political and population differences. It is therefore a call for all economic agents, government parastatals, Non-Governmental Organizations (NGOs) and well-meaning Nigerians to put in their best for the recovery and realization of our economy's independence to foreign aids such as refining of crude oil for the countries use, placing equal value or even more on Nigerian made products and goods, double import and reduces export duty services, Promoting research and implement results, improving the electricity supply to boost industrializations etc. More so, a flexible and quality healthcare plan that provides health insurance to her citizens should be implemented. On the other hand, there should be regular updating of student curriculum, improvement in the teaching standards and adoption of online studies, encouragement of academic performance through awards and opportunities, promotion of quality schools facilities, accessibilities to students loan/scholarships and creations of Students opportunities are some of the social and educational welfare policies 
needed to be implemented to war against similar pandemics.

\section{Recommendations}

The COVID-19 pandemic is a wake-up call to policymakers as the unusual and unprecedented nature of the crisis has made it impossible for citizens to rely on foreign health care services and more difficult to solicit for international support given the competing demand for medical supplies and equipment.

Secondly, it is critical to strengthen the public health systems, address the challenges posed by informality and implement reforms that will support strong and sustainable growth in the health sectors through public health preparedness and response team against any eventualities.

\section{Conflicts of Interest}

The authors declare no conflicts of interest regarding the publication of this paper.

\section{References}

[1] Muhammad, A.S., Suliman, K., Abeer, K., Nadia, B. and Rabeea, S. (2020) COVID-19 Infection: Origin, Transmission, and Characteristics of Human Coronaviruses. Journal of Advanced Research, 24, 91-98. https://doi.org/10.1016/j.jare.2020.03.005

[2] Center for Disease Prevention and Control (ECDPC) (2020) Situation Update Worldwide, as of 17 April, 2020.

[3] Worldometer (2020) Countries Where COVID-19 Has Spread, 2020.

[4] Owen, J. (2020) 20 of the Worst Epidemics and Pandemics in History: Livescience, 2020.

https://www.livescience.com/worst-epidemics-and-pandemics-in-history.html

[5] Devaux, C.A. (2013) Small Oversights That Led to the Great Plague of Marseille (1720-1723): Lessons from the Past. Infection, Genetics and Evolution, 14, 169-185. https://doi.org/10.1016/j.meegid.2012.11.016

[6] Tom O., Jamie, R., Maeva, C. and Jinshan, H. (2020) Coronavirus Could Cost the Global Economy \$2.7 Trillion. Bloomberg, 2020.

[7] Jones, L., Brown, D. and Palumbo, D. (2020) Coronavirus: A Visual Guide to the Economic Impact. BBC News, 3 April 2020.

https://www.unic.ac.cy/da/2020/05/08/coronavirus-a-visual-guide-to-the-economic -impact-bbc-news/

[8] Ogunde, O. (2020) The Impact of the Coronavirus Pandemic: Socioeconomic Pandemonium! Defence of Marxism, 14 April 2020.

[9] Nigerian Extractive Industries Transparency Initiatives (NEITI) (2020) FAAC Shared of N1.946 Trillion to FG, States, LGAs and Others in 2020 First Quarter, 2020 .

https://www.neiti.gov.ng/index.php/media-centre/news/502-faac-shared-n1-945-tril lion-to-fg-states-lgs-and-others-in-2020-first

[10] Rafael, C. (2014) How to Calculate Sample Size Using Taro Yamane's Formula. https://www.nairaproject.com/blog/its-taro-yamane-not-yaro.html

[11] Kothari, C.R. and Garg, G. (2016) Research Methodology: Methods and Tech- 
niques. 3rd Edition, New Age International Publishers, Delhi, 104-106.

[12] United Nations Educational, Scientific and Cultural Organization (2020) COVID-19 Educational Disruption and Response. United Nations Educational, Scientific and Cultural Organization, Paris.

[13] United Nations Educational, Scientific and Cultural Organization (2020) Adverse consequences of School Closure. United Nations Educational, Scientific and Cultural Organization, Paris.

[14] Dangi, R.R. and George, M. (2020) Psychological Perception of Students during COVID-19 Outbreak in India. High Technology Letters, 26, 142-148.

[15] Wang, G., Zhang, Y., Zhao, J., Zhang, J. and Jiang, F. (2020) Mitigate the Effects of Home Confinement on Children during the COVID-19 Outbreaks. The Lancet, 395, 945-947. https://doi.org/10.1016/S0140-6736(20)30547-X

[16] Sulkowski, L. and Ignatowski, G. (2020) Impact of COVID-19 Pandemic on Organization of Religious Behavior in Different Christian Denominations in Poland. Religion, 11, Article No. 254. https://doi.org/10.3390/rel11050254

[17] National Bureau of Statistics (NBS) (2020) Nigerian COVID-19 Impact Monitoring: A Baseline for Implementing the Nigeria COVID-19 through National Longitudinal Phone Survey (COVID-19 NLPS). https://www.nigerianstat.gov.ng/

[18] National Bureau of Statistics (NBS) (2020) Nigerian Capital Importation. First Quater Report. National Bureau of Statistics, Abuja.

[19] Ozili, P.K. (2020) COVID-19 Pandemic and Economic Crisis: The Nigerian Experience and Structural Causes. Article in SSRN Electronic Journal, 1-29. https://doi.org/10.2139/ssrn.3567419

[20] United Nations High Commissioner for Refugees (2015) Global Trends Forced Displacement in 2014. United Nations High Commissioner for Refugees, Geneva.

[21] Olanrewaju, O.F., Olanrewaju, A., Omotoso, F., Alabi, O.J., Amoo, E., Loromeke, E. and Adaina, L.A. (2019) Insurgency and the Invisible Displaced Population in Nigeria: A situational Analysis. SAGE Open, 9, 1-12. https://doi.org/10.1177\%2F2158244019846207

[22] Okon, E.O. (2018) Internally Displaced Persons in Nigeria: Review of Empirical Studies. American International Journal of Social Science Research, 2, 28-38. https://doi.org/10.46281/aijssr.v2i1.165

[23] Etikan, I. and Babatope, O. (2019) Health and Social Assessment of Internally Displaced People (IDP) in Nigeria. Annals of Biostatistics \& Biometric Applications, 2, 23-28. https://doi.org/10.33552/ABBA.2019.02.000543

[24] Roberts, E.R. and Okanya, O. (2020) Measuring the Socio-Economic Impact of Forced Evictions and Illegal Demolition: A Comparative Study between Displaced and Existing Informal Settlements. The Social Science Journal, 24, 1-20.

https://doi.org/10.1016/j.soscij.2018.12.003

[25] Giannakis, E. and Bruggeman, A. (2019) Economic Crisis and Regional Resilience: Evidence from Greece. Papers in Regional Science, 96, 451-476. https://doi.org/10.1111/pirs.12206

[26] World Health Organization (2020) Water, Sanitation, Hygiene and Waste Management for the COVID-19 Virus: Interim guidance. World Health Organization, Geneva.

[27] Ebuete, A.W., Isiya, S., Ndiwari, L.E., Ebuete, I.Y., Walson, P.T.A. and Wolisi, I.H. (2020) The Food and the Poison, a Retrospect of Abattoir, Butcher Markets and Buckateria in Nigeria: An empirical Study. American Journal of Epidemiology and Public Health, 4, 24-31. 